\title{
Enzyme supplementation of dry and wet wheat-based feeds for broiler chickens: performance and gut responses
}

\author{
S. Yasar† and J. M. Forbes* \\ Centre for Animal Sciences, Leeds Institute of Biotechnology and Agriculture, University of Leeds, Leeds LS2 9JT, UK
}

(Received 12 March 1999 - Revised 27 September 1999 - Accepted 20 January 2000)

\begin{abstract}
To test whether the improvements in digestive efficiency due to either wetting of the food or inclusion of enzymes are accompanied by the same changes in gut function, foods with a high content of wheat were fed to broiler chicks from 1-42 d old. Twenty-four birds were caged individually while a further sixty-four were in group pens in experiments of $2 \times 2$ factorial design with two levels of enzyme ( 0 or $1 \mathrm{~g} / \mathrm{kg}$, designed for wheat) and two levels of water addition ( 0 and $1300 \mathrm{~g} / \mathrm{kg}$ ). Food intake and live-weight gain were significantly increased by wet feeding (from 89.3 to $153.4 \mathrm{~g} / \mathrm{d}$ and from 39.7 to $65.4 \mathrm{~g} / \mathrm{d}$ respectively), the differences increasing with age, while the enzyme had no significant effect $(120.5$ and $122.2 \mathrm{~g} / \mathrm{d}$ and 51.9 and $53 \cdot 1 \mathrm{~g} /$ week respectively). The viscosity of digesta was greatly reduced both by wetting (from 4.40 to $2.64 \mathrm{kPa} \cdot \mathrm{s}$ ) and enzyme (from 4.47 to $2.57 \mathrm{kPa} \cdot \mathrm{s}$ ) but there was a significant interaction with age in which the viscosity was low throughout in the wet only, enzyme only and wet +enzyme treatments but declined with age from a very high level in the dry, no enzyme treatment $(11.5 \mathrm{kPa} \cdot \mathrm{s}$ at $14 \mathrm{~d})$. While wetting increased weight and length of digestive tract and thickness of some parts of the gut, enzyme had no significant effect, tending to reduce gut wall thickness. Crypt cell proliferation rate (CCPR) was significantly reduced by wet feeding (from 39.4 to 28.7 cells/crypt per $2 \mathrm{~h}$ ) and by enzyme supplementation (from 38.9 to 29.2 cells/crypt per $2 \mathrm{~h}$ ). Therefore, while both wetting and enzyme addition to the food reduced digesta viscosity and CCPR to a similar extent, the former had marked stimulatory effects on food intake and weight gain while the latter had little effect. The mode of action of wet feeding is therefore deduced to be not primarily through its effects on viscosity and CCPR.
\end{abstract}

\section{Growth: Gut histo-morphology: Wet food: Broiler chickens}

\begin{abstract}
Wetting cereal-based foods caused significant improvements in food intake, weight gain and/or feed conversion efficiency (FCE) of broiler chickens (Yalda \& Forbes, 1995, 1996; Yasar \& Forbes, 1999). This was accompanied by changes in the epithelial structure of the gut (Yasar, 1998). Although wet feeding of cereal-based foods caused significant reduction in digesta viscosity, birds given wet foods did not convert food to live weight much more efficiently than those given dry foods (Yasar \& Forbes, 1999), in contrast to the results of Yalda \& Forbes $(1995,1996)$ with commercial standard foods. Inclusion of a high proportion of wheat in commercial broiler diets introduces an appreciable amount of viscous-gel-forming NSP pentosans into the intestinal lumen (Annison, 1991). Apart from problems such as sticky droppings that cause management difficulties in poultry production, an increase in viscosity of digesta due to NSP retards the passage of food throughout the tract (Edwards et al. 1992; Almirall \& Garcia, 1994) and renders digestive
\end{abstract}

enzymes and secretions less able to penetrate the food particles efficiently, thereby causing poor utilisation of nutrients during digestion and absorption (Choct \& Annison, 1990, 1992; Van Der Klis et al. 1993a,b).

Numerous studies have reported improvements in the nutritional value of cereal-based foods with enzyme addition through reductions in digesta viscosity, suggesting partial degradation of NSP in the gut by endogenous feed enzymes (Moran et al. 1969; Fengler \& Marquardt, 1988; Fengler et al. 1988; Petterson \& Aman, 1989; Pawlic et al. 1990; Bedford et al. 1991; Bedford \& Classen, 1992). Recently it has been found that when enzyme addition to a standard dry food, which improved performance of broilers with an improvement in FCE, was coupled with wet feeding there was a significant additive response in performance (Yalda \& Forbes, 1996). This was proposed to be mediated by a reduction in digesta viscosity. If highly viscous digesta is a cause of poor nutrient utilisation of

\footnotetext{
Abbreviations: CCPR, crypt cell proliferation rate; FCE, feed conversion efficiency.

* Corresponding author: Professor J. M. Forbes, fax +44 1132 33072, email j.m.forbes@leeds.ac.uk

$\uparrow$ Present address: Suleyman Demirel University, Ziraat Fakultesi, Zootekni Bolumu, Atabey - Isparta, Turkey.
} 
high-cereal foods by poultry, then using enzymes and/or wet feeding to reduce viscosity should improve nutritional value of high-cereal foodstuffs even more than they improve utilisation of foods low in cereals.

In order to test this hypothesis an experiment was carried out with broiler chickens offered wet and dry wheat-based foods with or without the addition of enzyme.

\section{Materials and methods}

\section{Animals and management}

Male broiler chicks ( $1 \mathrm{~d}$ old) of a commercial strain (Ross; Mayfield Hatcheries, Rossendale, Lancs., UK) were kept in floor pens in groups on a commercial starter crumb (J. Bibby Agriculture Ltd. Adderbury, Banbury, Oxon, UK; crude protein $230 \mathrm{~g} / \mathrm{kg}$, crude fibre $30 \mathrm{~g} / \mathrm{kg}$, total oil $53 \mathrm{~g} / \mathrm{kg}$ ) at an environmental temperature of $33^{\circ} \mathrm{C}$ for $7 \mathrm{~d}$. They were then transferred to cages in a room in which the temperature was decreased by $4^{\circ} \mathrm{C}$ every week to reach $22^{\circ} \mathrm{C}$ by $23 \mathrm{~d}$ old, and then maintained at about $22^{\circ} \mathrm{C}$ to $42 \mathrm{~d}$ old with continuous lighting.

For individual monitoring of food and water intakes, and excreta outputs, twenty-four birds with similar live weights were transferred into individual cages at $7 \mathrm{~d}$ old. They were divided into four treatments, each with six birds and with similar average live weight. The design of the experiment was a $2 \times 2$ factorial with two levels of enzyme addition $(0$ and $1 \mathrm{~g} / \mathrm{kg}$ food) and two water additions (dry and $1.3 \mathrm{~kg}$ water/kg air-dry food).

At the same time, additional birds were reared in floor pens to be killed every week of the experiment. Birds ( $n$ 64, $7 \mathrm{~d}$ old) were kept in four floor pens, each containing sixteen birds, and offered the experimental foods from 7 to $42 \mathrm{~d}$ old. Four birds from each pen were killed at 14, 21, 28 and $35 \mathrm{~d}$ old for collection of gut contents for viscosity determination and measurement of gut size. Tissue samples from various digestive segments were obtained from the four birds from each treatment killed at $28 \mathrm{~d}$ old for determination of crypt cell proliferation rate (CCPR) and histo-morphologic variables.

\section{Feeds and feeding}

All grains were ground through a hammer mill (Fritsch Industriestr. 8, 6580 Idar-Oberstein, W. Germany) to pass through a $4 \mathrm{~mm}$ sieve.

Wheat-based food was offered to $7 \mathrm{~d}$ old broiler chicks in two forms: air-dried or wet, unsupplemented or supplemented with the appropriate enzyme. The enzyme was added to food by first mixing it with a small proportion of ground cereal grain which was then mixed with the rest of the food ingredients. The experimental food was wheatbased, and its nutrient composition is given in Table 1 . Wheat grain was obtained from Dalgety Agriculture Ltd (Bristol, UK), estimated to produce a high viscosity. The feed enzyme used (with activities of $2700 \mathrm{U}$ xylanase/g, $<70 \mathrm{U} \beta$-glucanase/g, $700 \mathrm{U}$ bacillus protease/g, included at $1 \mathrm{~g} / \mathrm{kg}$, the level of inclusion recommended by the suppliers, Finnfeeds International, Marlborough, Wilts., UK) was of fungal origin. The appropriate porridge-like
Table 1. Composition of experimental foods

\begin{tabular}{lcc}
\hline Ingredients $(\mathrm{g} / \mathrm{kg})$ & Starter diet & Finisher diet \\
\hline Wheat & 626 & 700 \\
Soyabean meal $(523 \mathrm{~g} \mathrm{CP} / \mathrm{kg})$ & 200 & 164 \\
Fish meal $(678 \mathrm{~g} \mathrm{CP} / \mathrm{kg})$ & 100 & 80 \\
Corn oil & 48 & 30 \\
Methionine & $1 \cdot 0$ & $1 \cdot 0$ \\
Tricalcium orthophosphate & $10 \cdot 0$ & $10 \cdot 0$ \\
Vitamin and mineral mixture & $12 \cdot 0$ & $12 \cdot 0$ \\
Chromic oxide† & $3 \cdot 0$ & 3.0 \\
Estimated composition (per kg DM) & & \\
$\quad$ Crude protein (g) & 243 & 214 \\
Metabolisable energy (MJ) & $12 \cdot 7$ & $12 \cdot 8$ \\
\hline
\end{tabular}

$\mathrm{CP}$, crude protein.

*Vitamin and mineral premix supplied the following (per kg): vitamin A $1440 \mathrm{mg}$; vitamin $D_{3} 30$ mg; vitamin E $10000 \mathrm{mg} ; \mathrm{Ca} 268 \mathrm{~g} ; \mathrm{Na} 80 \mathrm{~g} ; \mathrm{Cu}, 4000 \mathrm{mg}$ as cupric sulphate; Se $80 \mathrm{mg}$ as sodium selenite; Mo $400 \mathrm{mg}$ as sodium molybdate.

†Experimental food with $\mathrm{Cr}_{2} \mathrm{O}_{3}$ as a marker to measure digestibility of food nutrients (results not reported in this paper).

consistency of the wet foods was achieved by adding $1.3 \mathrm{~kg}$ water $/ \mathrm{kg}$ food. Food and water intake were recorded daily and live weight weekly throughout the experimental period, from 7 to $42 \mathrm{~d}$ old.

Wet foods were prepared fresh daily by adding $1.3 \mathrm{~kg}$ tap water to each kg of air-dry food and offered to the chicks immediately after achieving a homogeneous mixture. The time interval between wetting and delivery of food to the birds was about $15 \mathrm{~min}$ and wet food would therefore have an average of $12 \mathrm{~h}$ soaking period during each $24 \mathrm{~h}$. This amount of water gave an appropriate semi-liquid porridge consistency as more than this resulted in a water layer above the bulk, deterring chicks from feeding.

Food refusals were discarded each day at about 09.00 hours to avoid mould growth, and clean containers were used every day. Samples of the refusals of wet food were collected once per week to study the effect of evaporation on DM content of wet food and allow calculation of actual DM intakes. Any waste food was collected from the trays underneath the cages and food intake corrected accordingly.

Food intake and water intake from nipple bottles were calculated daily. Total daily water intake was expressed as apparent daily water intake plus water taken in through the food eaten during a $24 \mathrm{~h}$ period. Live weight of birds was recorded at the start of each experiment, and then every week.

\section{Dry matter retention}

The excreta of the birds in cages were collected on metal trays for four consecutive days in every week and then frozen. All excreta from each $4 \mathrm{~d}$ collection were thawed, mixed and dried at $105^{\circ} \mathrm{C}$ for the measurement of the apparent retention of DM as a proportion of DM intake.

\section{Post-mortem measurements}

After killing birds by immersion in $\mathrm{CO}_{2}$ the entire digestive tract was removed and divided into crop, proventriculus plus gizzard, duodenum (pancreatic loop only), proximal third, middle third and distal third of small intestine, caecum and colon. The length and full weight of each 
segment was recorded, its contents milked out, and the segments re-weighed empty. Where DM of digesta were determined, some of the mixed digesta was placed in $\mathrm{Al}$ evaporating dishes to dry in an oven at $107^{\circ} \mathrm{C}$. The remaining digesta sample from each segment was centrifuged at $900 \mathrm{~g}$ for $30 \mathrm{~min}$ after which approximately $0.5 \mathrm{ml}$ supernatant was placed in a digital, cone-plate viscometer (model LVTD-CP-40; Brookfield Engineering Laboratories, Inc., Middleboro, MA, USA), and the viscosity $(\mathrm{kPa} \cdot \mathrm{s})$ measured at $41^{\circ} \mathrm{C}$ (deep body temperature of bird) at 50 r.p.m. It was not possible to obtain clear supernatant from digesta from caeca and colons.

CCPR was measured in five birds per treatment by injecting vincristine sulfate in distilled water $(1 \mathrm{mg} / \mathrm{kg}$ body weight) intraperitoneally and killing $2 \mathrm{~h}$ later. Vincristine sulfate is a stathmokinetic (metaphase arrest) drug which interacts with the mitotic spindle to block cells in metaphase within the epithelial crypt of where cell renewal occurs in the intestine. The accumulation of these arrested metaphases represents the rate of cell proliferation and is expressed as cells/crypt per $2 \mathrm{~h}$ (Goodlad \& Wright, 1982).

Two tissue samples each $10 \mathrm{~mm}$ long were cut from the midpoints of the digestive segments, one of which was fixed in formal-saline, dehydrated with ethanol in increasing concentrations, embedded, sectioned $(5 \mu \mathrm{m})$ and stained with haematoxylin and eosin. Slides were examined under a light microscope (up to $\times 400$ magnification) and the thickness of tissue layers, villi heights, crypt depths and thickness of tunica muscularis were measured at six or nine points of each slide using a graticule (100 $\mu \mathrm{m}$ divisions) placed in the eye-piece of the microscope. Although the mucosa lining folds in the wall of the caecum and colon are not villi in the strict sense, they have been called such by Bell \& Freeman (1971) and Turk (1982).

The second samples were prepared for estimate of CCPR by counting of darkly-stained dividing cells for twelve entire crypts in each sample (broken or overlapping crypts were ignored).

\section{Statistical analysis}

The data from the individually-caged birds were statistically analysed using GLM model (Minitab for Windows, Statistical software, release 9.2 (1993); Minitab Inc., PA, USA) of
ANOVA with a factorial arrangement of $2 \times 2$ (level of enzyme $\times$ form of food) with day of experiment as a repeated measure. The data from the groups were similarly analysed using ANOVA (two levels of wetness $\times$ two levels of enzyme) with repeated measures (week).

\section{Results}

Food intake, live-weight gain, feed conversion efficiency, dry matter retention and water intake

The effect of wetting wheat-based food on food intake and live-weight gain of broiler chickens was found to be highly significant $(P<0.001)$, whereas supplementation of the same food with enzyme did not significantly affect food intake or live-weight gain (Table 2).

FCE (g weight gain/g food eaten) and DM retention were not significantly $(P>0.05)$ affected by wetting or enzyme addition. There was a significant interaction between the effects of wetness and week on food intake and live-weight gain: Fig. 1 clearly indicates that the difference between intake for dry food and wet food increased as the experiment progressed and this was also true for live-weight gain (Fig. 2).

Total water intakes (from food and drinker) were proportional to dry food intakes, with values of 188 and $110 \mathrm{~g} / \mathrm{d}$ for wet- and dry-fed birds respectively $(P<0.001$, SEM 2.53); the overall means with and without enzyme were 145 and 154 respectively $(P<0 \cdot 05$, SEM 2.53$)$. The water: food ratios were thus $1.36,1.26,1.28$ and $1.34 \mathrm{~g} / \mathrm{g}$ (NS, SEM 0.03) for dry food, wet food, food without enzyme and food with enzyme respectively.

\section{Digesta viscosity}

Wetting wheat-based food significantly $(P<0.001)$ reduced the viscosity of the gut contents, compared with dry food with the same nutrient composition; the values were 2.64 and $4.40 \mathrm{kPa} \cdot \mathrm{s}$ (SEM $0 \cdot 18$ ) for wet food and dry food respectively. Addition of enzyme to wheat-based food also significantly $(P<0.001)$ reduced digesta viscosity in gut contents over the whole digestive tract, from a mean of 4.47 for food without enzyme to one of $2.57 \mathrm{kPa} \cdot \mathrm{s}$ for food with enzyme respectively (SEM $0 \cdot 18$ ).

Table 2. Feed intake, live-weight gain, feed conversion efficiency and dry matter retention in broiler chickens from 7 to $35 \mathrm{~d}$ post-hatching, given a wet and dry wheat-based diet with or without enzyme†

(Mean values for six broiler chickens per group)

\begin{tabular}{|c|c|c|c|c|c|c|}
\hline \multirow[b]{2}{*}{ Treatment ... } & \multicolumn{2}{|c|}{ Food type } & \multicolumn{2}{|c|}{ Enzyme } & \multicolumn{2}{|c|}{$\begin{array}{l}\text { wetting } \times \text { age } \\
(\text { ANOVA) }\end{array}$} \\
\hline & Dry & Wet & Without & With & SEM & $P$ \\
\hline $\begin{array}{l}\text { Feed intake (g air-dried feed/d) } \\
\text { Live-weight gain (g/week) } \\
\text { Feed conversion efficiency (live-weight gain (g)/feed intake (g)) } \\
\text { Dry matter retention (g/kg food DM) }\end{array}$ & $\begin{array}{c}89 \cdot 3 \\
277 \cdot 7 \\
0.446 \\
750 \cdot 1\end{array}$ & $\begin{array}{l}153 \cdot 4^{* * *} \\
457 \cdot 8^{\star * *} \\
0 \cdot 427 \\
757 \cdot 5\end{array}$ & $\begin{array}{l}120.5 \\
363.5 \\
0.432 \\
743.5\end{array}$ & $\begin{array}{l}122 \cdot 2 \\
372 \cdot 0 \\
0 \cdot 441 \\
764 \cdot 1\end{array}$ & $\begin{array}{c}1.72 \\
14 \cdot 5 \\
0 \cdot 01 \\
16 \cdot 6\end{array}$ & $\begin{array}{l}<0.001 \\
<0.05 \\
\text { NS } \\
\text { NS }\end{array}$ \\
\hline
\end{tabular}

Mean values were significantly different from those of dry-diet group: ${ }^{* \star \star} P<0.001$.

†For details of diet see Table 1 and p. 298. The wet diet was made by addition of $1.3 \mathrm{~kg}$ water to $1 \mathrm{~kg}$ air-dried diet. The feed enzyme was included at $1 \mathrm{~g} / \mathrm{kg}$ and contained (U/g): xylanase 2700; $\beta$-glucanase < 70; bacillus protease 700 (Finnfeeds International, Marlborough, Wilts., UK). 


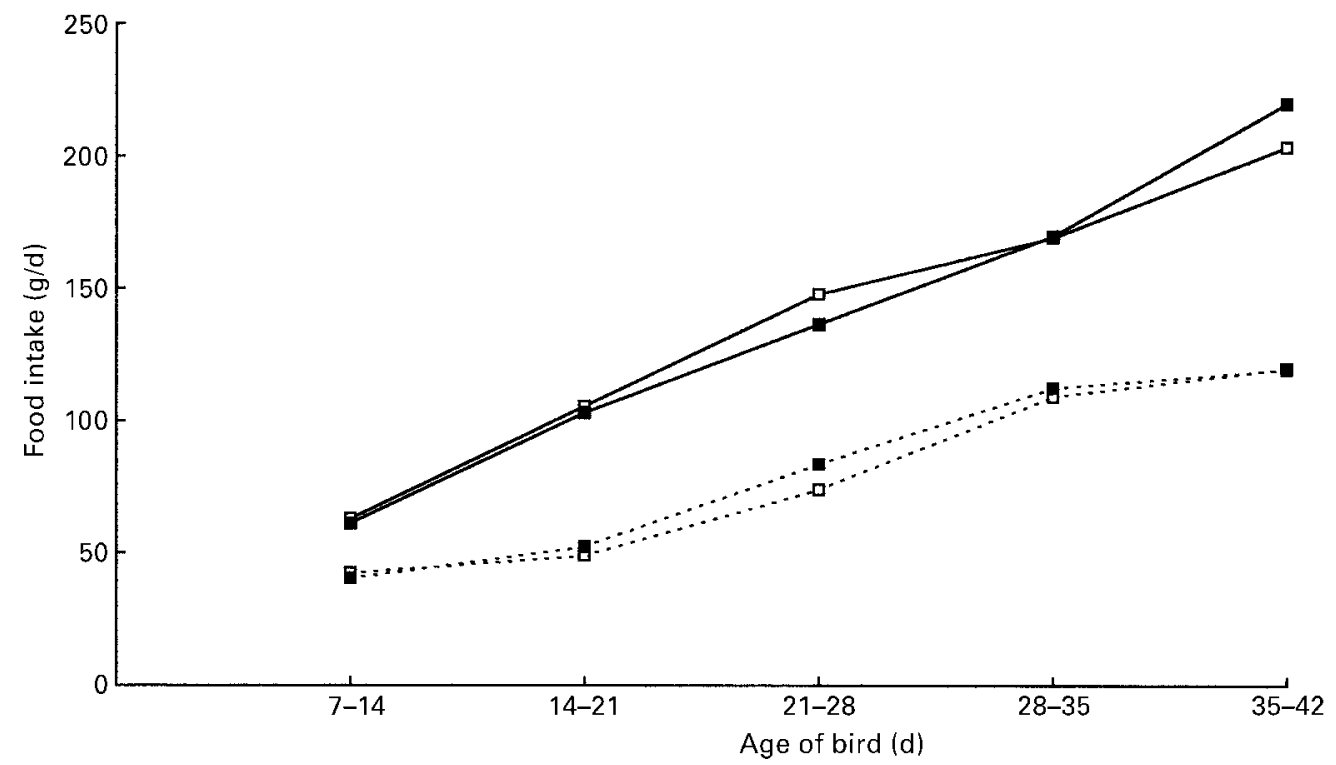

Fig. 1. Food intake (g DM/d) of broiler chicken ( $n 6$ per group) fed on a wheat-based diet given in dry $(----)$ or wet $(-\longrightarrow)$ form with ( $\square$ ) or without $(\square)$ added enzyme; SEM 1.72 . For details of the diet see Table 1 and p. 298. The wet diet was made by addition of $1.3 \mathrm{~kg}$ water to $1 \mathrm{~kg}$ airdried diet. The feed enzyme was included at $1 \mathrm{~g} / \mathrm{kg}$ and contained $(\mathrm{U} / \mathrm{g})$ : xylanase 2700; $\beta$-glucanase $<70$; bacillus protease 700 (Finnfeeds International, Marlborough, Wilts., UK).

The interaction between wetting and enzyme addition was found to be significant on the overall viscosity values of the gut contents, and this was seen throughout the experimental period, from $14 \mathrm{~d}$ to $35 \mathrm{~d}$ old (Fig. 3). The viscosity of digesta in the gut was greatly increased in broiler chickens given dry food without enzyme addition, while offering dry or wet foods with addition of enzyme significantly reduced the viscosity of digesta. Fig. 3 also shows that the digesta viscosity in the gut for the dry noenzyme treatment declined markedly as the birds got older so that there was comparatively little difference between treatments from $28 \mathrm{~d}$.

The viscosity of the chyme in the upper segments of digestive tract (crop, proventriculus plus gizzard, and duodenum) was similar in all treatment groups, whereas in the lower segments of the tract (proximal, middle and distal parts of the small intestine) the birds receiving dry food without enzyme produced significantly higher viscosities than those given wet food with or without enzyme and dry food with enzyme; Fig. 4 presents a summary of the

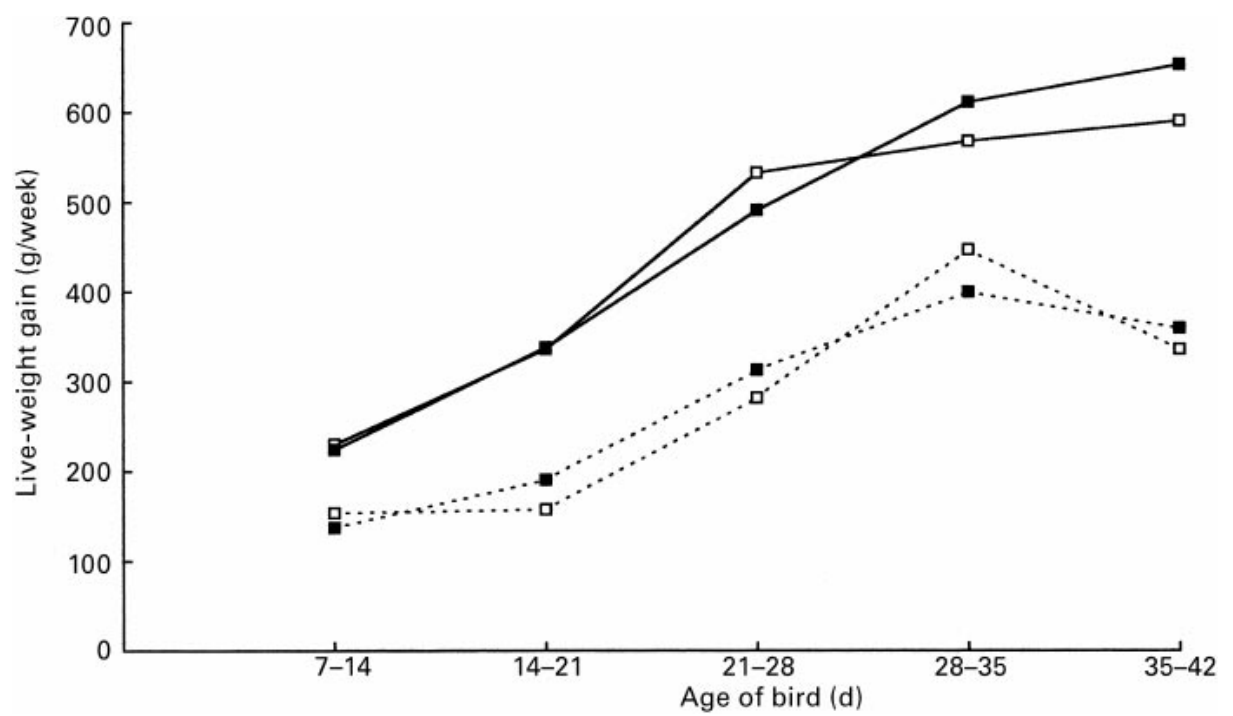

Fig. 2. Live-weight gain (g/week) of broiler chickens ( $n 6$ per group) fed on a wheat-based diet given in dry (- - - ) or wet (- - ) form with ( $\square$ ) or without $(\square)$ added enzyme; SEM 14.5. For details of the diet see Table 1 and p. 298. The wet diet was made by addition of $1.3 \mathrm{~kg}$ water to $1 \mathrm{~kg}$ airdried diet. The feed enzyme was included at $1 \mathrm{~g} / \mathrm{kg}$ and contained $(\mathrm{U} / \mathrm{g})$ : xylanase $2700 ; \beta$-glucanase $<70$; bacillus protease 700 (Finnfeeds International, Marlborough, Wilts., UK). 


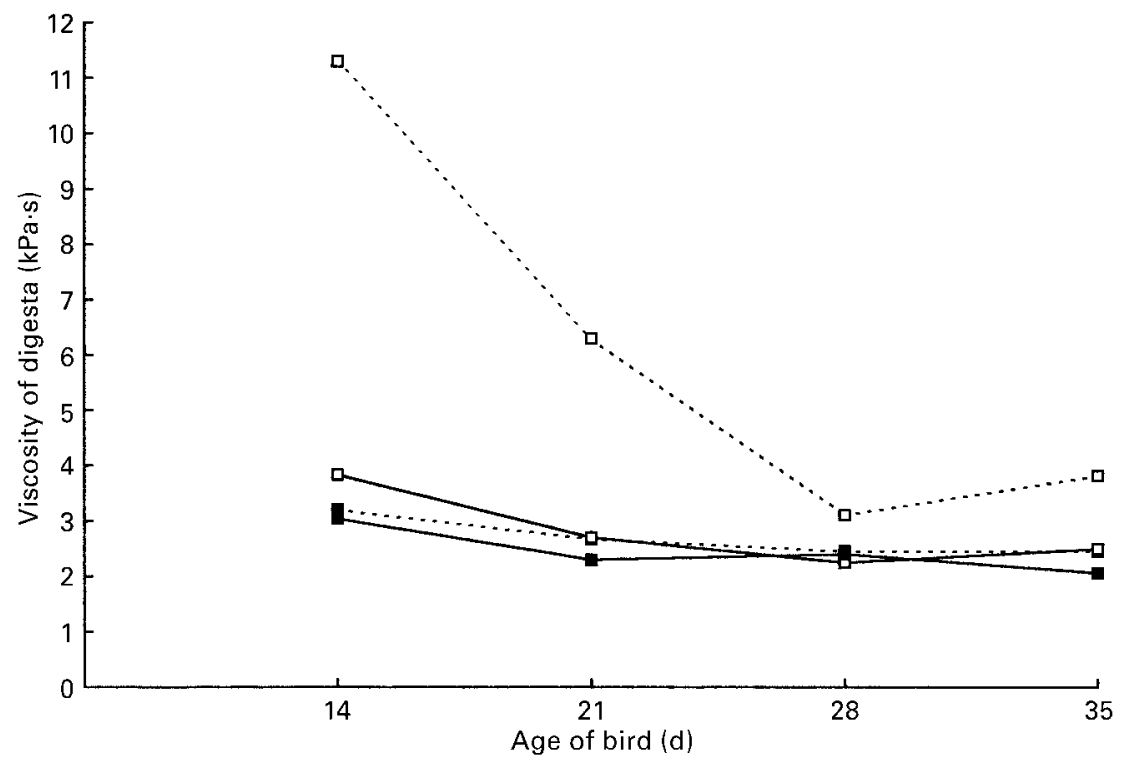

Fig. 3. Digesta viscosity of the gut contents (mean values for six segments) of broiler chickens ( $n 4$ per group). Fed on a wheat-based diet given in dry $(----)$ or wet $(-)$ form with $(\square)$ or without $(\square)$ added enzyme; SEM 0.18 . For details of diet see Table 1 and p. 298. The wet diet was made by addition of $1.3 \mathrm{~kg}$ water to $1 \mathrm{~kg}$ air-dried diet. The feed enzyme was included at $1 \mathrm{~g} / \mathrm{kg}$ and contained (U/g): xylanase $2700 ; \beta$-glucanase $<70$; bacillus protease 700 (Finnfeeds International, Marlborough, Wilts., UK).

results as means for birds killed at $14,21,28$ and $35 \mathrm{~d}$ post-hatching.

\section{Gut dimensions}

The length of the entire gut was significantly $(P<0 \cdot 05)$ increased by wetting but not by addition of enzyme (Table 3) but there was a significant interaction whereby addition of enzyme to dry food significantly increased the gut length from $154.8 \mathrm{~cm}$ for dry food without enzyme to $162.2 \mathrm{~cm}$ (SEM 3.05) while a decrease in the gut length from 168.0 for wet food without enzyme to $162.4 \mathrm{~cm}$ for wet food with enzyme (SEM 3.05) was not significant. The effect of enzyme addition and wetting on the length of individual segments was, however, not found to be significant (Table 3).

The main effects of treatments on the full and empty weight of the whole gut in broiler chickens are given in Table 3, from which it can be noted that wetting significantly $(P<0.05)$ increased both full and empty weight of the gut while the effect of enzyme addition was not significant. The interaction between enzyme and wetting was significant on empty-gut weight but not on full-gut weight: enzyme addition to dry-wheat food significantly

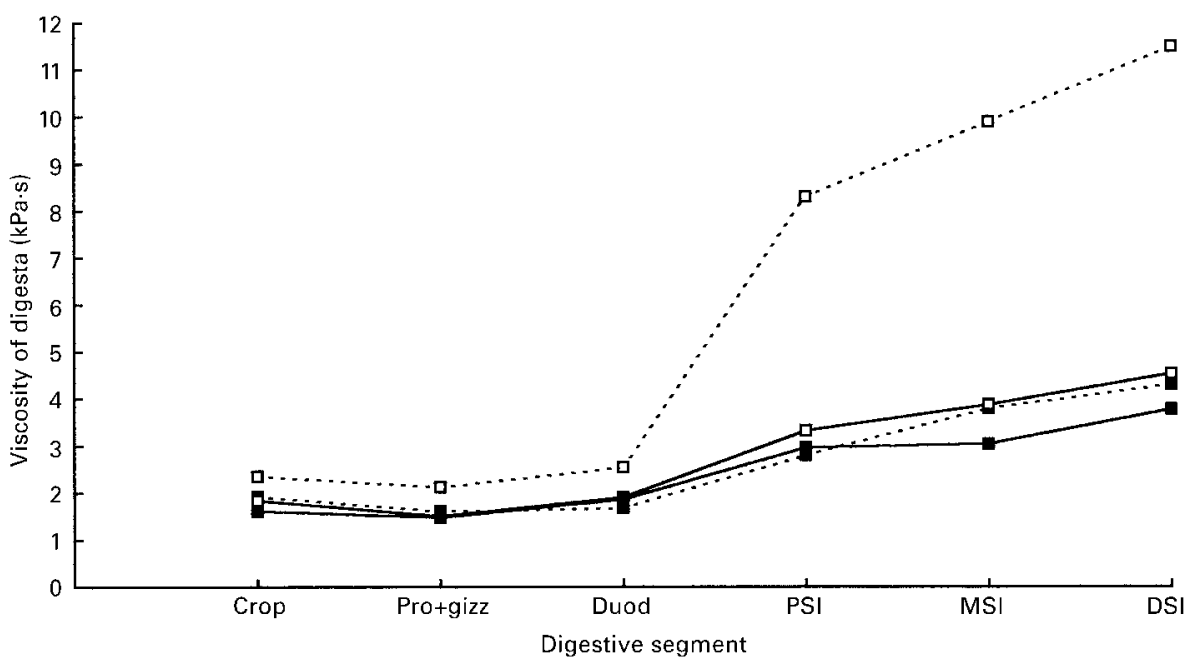

Fig. 4. Digesta viscosity in different gastrointestinal segments of broiler chickens ( $n 4$ per group) fed on a wheat-based diet given in dry (- - - -) or wet $(-)$ form with $(\square)$ or without $(\square)$ added enzyme. Values are means from birds killed at $14,21,28$ and $35 \mathrm{~d}$ post-hatching (SEM 0.18). Pro + gizz, proventriculus and gizzard; Duod, duodenum; PSI, proximal small intestine; MSI, middle small intestine; DSI, distal small intestine. For details of diet see Table 1 and p. 298. The wet diet was made by addition of $1.3 \mathrm{~kg}$ water to $1 \mathrm{~kg}$ air-dried diet. The feed enzyme was included at $1 \mathrm{~g} / \mathrm{kg}$ and contained (U/g): xylanase 2700, $\beta$-glucanase $<70$; bacillus protease 700 (Finnfeeds International, Marlborough, Wilts., UK). 
Table 3. Treatment means and results of statistical analyses for gut length (cm), full gut weight $(\mathrm{g})$, empty gut weight (g) relative empty gut weight in broiler chickens given wet and dry food of a wheat-based diet supplemented with or without enzyme $\dagger$

(Mean values for four broiler chickens per group)

\begin{tabular}{|c|c|c|c|c|c|c|}
\hline \multirow[b]{2}{*}{ Treatment . } & \multicolumn{2}{|c|}{ Food type } & \multicolumn{2}{|c|}{ Enzyme } & \multirow[b]{2}{*}{ SEM } & \multirow{2}{*}{$\begin{array}{c}\text { Significance of } \\
\text { interactions }\end{array}$} \\
\hline & Dry & Wet & Without & With & & \\
\hline Gut length $(\mathrm{cm})$ & 158.5 & $165 \cdot 2^{*}$ & 161.4 & $162 \cdot 3$ & $2 \cdot 15$ & $\S$ \\
\hline Full-gut weight (g) & 133.4 & $168 \cdot 7^{*}$ & $144 \cdot 6$ & 157.5 & 4.72 & $\|$ \\
\hline Empty gut weight (q) & 78.60 & $85.72^{*}$ & 81.55 & 82.80 & 2.06 & g \\
\hline Relative gut weight ( $\mathrm{g} / \mathrm{kg}$ body weight) & $84 \cdot 4$ & 82.6 & 85.6 & $81 \cdot 4^{*}$ & $1 \cdot 1$ & ** \\
\hline \multicolumn{7}{|l|}{ Length of digestive segment $(\mathrm{cm})$} \\
\hline Crop & 9.54 & $10 \cdot 3$ & $9 \cdot 61$ & $10 \cdot 22$ & 0.51 & \\
\hline Proventriculus + gizzard & 9.53 & $9 \cdot 73$ & $9 \cdot 6$ & $9 \cdot 73$ & & \\
\hline Duodenum & 24.2 & $25 \cdot 3$ & 24.8 & 24.6 & & \\
\hline Proximal SI & 37.5 & $39 \cdot 3$ & 38.5 & 38.2 & & \\
\hline Middle SI & 37.5 & 38.4 & 38.5 & 38.2 & & \\
\hline Distal SI & 37.5 & 38.4 & 38.5 & 38.2 & & \\
\hline Caecum & 13.36 & $13 \cdot 4$ & $13 \cdot 4$ & $13 \cdot 2$ & & \\
\hline Colon & 7.65 & 7.02 & 7.04 & 7.25 & & \\
\hline \multicolumn{7}{|l|}{ Empty weights (g) } \\
\hline Crop & $5 \cdot 75$ & 7.5 & $6 \cdot 21$ & $7 \cdot 04$ & 0.44 & \\
\hline Proventriculus + gizzard & $30 \cdot 23$ & 33.21 & 31.9 & 31.52 & & \\
\hline Duodenum & 7.54 & 8.22 & 7.85 & 7.92 & & \\
\hline Proximal SI & $10 \cdot 43$ & 11.46 & $10 \cdot 8$ & 11.08 & & \\
\hline Middle SI & 8.84 & 9.84 & $9 \cdot 45$ & $9 \cdot 24$ & & \\
\hline Distal SI & 7.57 & 8.45 & 7.88 & 8.14 & & \\
\hline Caecum & $5 \cdot 14$ & 4.73 & 4.8 & 5.07 & & \\
\hline Colon & 3.00 & 2.52 & 2.73 & $2 \cdot 74$ & & \\
\hline \multicolumn{7}{|c|}{ The amount of digesta in digestive segment (g) } \\
\hline Crop & $14 \cdot 30$ & $34 \cdot 81^{*}$ & 19.64 & 29.47 & 1.97 & \\
\hline Proventriculus + gizzard & 13.36 & 15.77 & 14.47 & 14.66 & & \\
\hline Duodenum & 1.66 & 1.73 & 1.58 & 1.80 & & \\
\hline Proximal SI & 7.32 & $9 \cdot 26$ & 7.92 & 8.67 & & \\
\hline Middle SI & $6 \cdot 76$ & $9 \cdot 23^{*}$ & $8 \cdot 14$ & 7.85 & & \\
\hline Distal SI & 4.35 & $6 \cdot 00^{*}$ & $5 \cdot 17$ & $5 \cdot 17$ & & \\
\hline Caecum & 4.97 & 4.91 & 4.66 & 5.22 & & \\
\hline Colon & 1.92 & 1.60 & 1.69 & 1.82 & & \\
\hline
\end{tabular}

SI, small intestine.

Mean values were significantly different from that of dry-diet group: * $P<0.05$.

$\dagger$ For details of diet see Table 1 and p. 298. The wet diet was made by addition of $1.3 \mathrm{~kg}$ water to $1 \mathrm{~kg}$ air-dried diet. The feed enzyme was included at $1 \mathrm{~g} / \mathrm{kg}$ and contained $(\mathrm{U} / \mathrm{g}$ ): xylanase 2700; $\beta$-glucanase < 70; bacillus protease 700 (Finnfeeds International, Marlborough, Wilts., UK).

$\ddagger$ The only other significant differences and interactions were as shown (see p. 000 for details).

$\S$ Significant main effect of age $(P<0.001)$, interaction between effects of wetting $\times$ enzyme $(P<0.05)$, enzyme $\times$ age $(P<0.05)$.

$\|$ Significant main effect of age $(P<0.001)$, interaction between effects of enzyme $\times$ age $(P<0.05)$.

I Significant main effect of age $(P<0.001)$, interaction between effects of wetting $\times$ enzyme $(P<0.01)$.

${ }^{* \star}$ Significant interaction between effects of enzyme $\times$ week $(P<0.05)$.

$(P<0 \cdot 05)$ increased empty-gut weight compared with dry-wheat food without enzyme $(73.6$ v. $83.6 \mathrm{~g} / \mathrm{bird}$ respectively), whereas there was a significant decrease in empty-gut weight with enzyme addition to wet-wheat food compared with wet-wheat food without enzyme (89.45 v. $82.0 \mathrm{~g}$, respectively). Empty weights of individual digestive segments tended to increase with wet feeding and enzyme supplementation, but the differences in these treatment groups were not found to be significant (Table 3). The relative empty-gut weight (empty-gut weight/kg live weight) was found to be unaffected by wetting. However, the values were numerically lower in birds given wet foods than those given dry foods (Table 3 ). There was a significant $(P<0.05)$ reduction in the relative gut weight with food with added enzyme, compared with food without enzyme.

Wetting wheat-based food resulted in significant increases in the amount of fresh digesta in the gut (54.8 for dry-wheat food v. 83.0 g for wet-wheat food (SEM 5.6) respectively). This showed that the gut capacity increased by $33 \%$ with wet food compared with dry food. Although enzyme addition had no significant effect on fresh digesta contents, the birds given food with enzyme tended to have more fresh digesta in the gut than the birds given food without enzyme (63.0v. 74.7 g (SEM 5.6) respectively). The amount of fresh digesta in the crop, the middle third and the distal third of small intestine was found to be significantly higher in wet-fed birds than in dry-fed birds (Table 3).

\section{Gut histo-morphology}

The thickness of proventricular tissue wall, proventricular gland, mucosa lining folds and muscle layer were significantly $(P<0.05)$ increased by wetting food but not by enzyme supplementation. However, the interaction between effects of wetting and enzyme addition were found to be significant $(P<0.05)$ on the thickness of these proventricular tissue layers, except the thickness of muscle layer (Table 4). A decrease in the thickness of all tissue layers in the proventriculus by enzyme addition was, however, not found to be significant $(P>0 \cdot 05)$. Enzyme addition to dry 
Table 4. Thickness $(\mu \mathrm{m})$ of proventricular tissue wall, glands, mucosa lining; tunica muscularis thickness ( $\mu \mathrm{m})$ of gizzard glands and gizzard-lining; villi height $(\mu \mathrm{m})$, crypt depth $(\mu \mathrm{m})$, the thickness of tunica muscularis $(\mu \mathrm{m})$, and the number of crypts per villi of the epithelium of the small intestine in broiler chickens given wet and dry food of a wheat-based diet supplemented with or without enzyme†

(Mean values for four broiler chickens per group)

\begin{tabular}{|c|c|c|c|c|c|c|c|c|c|c|}
\hline \multirow[b]{2}{*}{ Treatment ... } & \multicolumn{2}{|c|}{ Food type } & \multicolumn{2}{|c|}{ Enzyme } & \multicolumn{6}{|c|}{ Significance of treatment effects } \\
\hline & Dry & Wet & Without & With & SEM & W & $E$ & S & $W \times E$ & $W \times E \times S$ \\
\hline \multicolumn{11}{|l|}{ Proventriculus } \\
\hline Wall $(\mu \mathrm{m})$ & 4542 & $4752 \ddagger$ & 4687 & 4607 & $54 \cdot 2$ & ** & NS & & \multicolumn{2}{|r|}{ 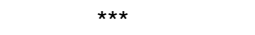 } \\
\hline Glands $(\mu \mathrm{m})$ & $3410 \cdot 7$ & $3489.0 \ddagger$ & 3484 & 3415 & $22 \cdot 07$ & ** & NS & & \multicolumn{2}{|c|}{ 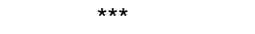 } \\
\hline Mucosa lining folds ( $\mu \mathrm{m})$ & 624 & $693 \ddagger$ & 653.7 & 663.6 & 17.89 & ** & NS & & \multicolumn{2}{|c|}{ ** } \\
\hline \multicolumn{11}{|l|}{ Gizzard } \\
\hline Tunica muscularis $(\mu \mathrm{m})$ & $507 \cdot 3$ & $570.0 \ddagger$ & $549 \cdot 0$ & $528 \cdot 3$ & 14.24 & ** & NS & & \multicolumn{2}{|r|}{ NS } \\
\hline Glands $(\mu \mathrm{m})$ & $454 \cdot 3$ & $492 \cdot 8$ & 546.5 & $400 \cdot 6 \ddagger$ & 17.09 & NS & $\star \star \star *$ & & \multicolumn{2}{|r|}{ NS } \\
\hline Mucosal lining $(\mu \mathrm{m})$ & 474.4 & $528 \cdot 3$ & $562 \cdot 1$ & $440.6 \ddagger$ & $25 \cdot 76$ & NS & ** & & \multicolumn{2}{|r|}{ NS } \\
\hline \multicolumn{11}{|l|}{ Small intestine } \\
\hline Villi height $(\mu \mathrm{m})$ & 748.6 & $799 \cdot 7 \ddagger$ & 769.6 & 778.8 & $6 \cdot 91$ & *** & NS & *** & ** & *** \\
\hline Crypt depth $(\mu \mathrm{m})$ & 95.0 & $115 \cdot 1 \neq$ & 104.1 & 105.9 & 1.7 & ** & NS & *** & ** & * \\
\hline Thickness of tunica muscularis $(\mu \mathrm{m})$ & $279 \cdot 4$ & $320 \cdot 0 \ddagger$ & $290 \cdot 1$ & $309 \cdot 1 \ddagger$ & 4.01 & $* \star *$ & ** & 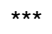 & $\star \star \star *$ & NS \\
\hline Crypts per villus $(n)$ & 3.35 & $3.78 \ddagger$ & 3.60 & 3.53 & 0.048 & *** & NS & *** & *** & *** \\
\hline
\end{tabular}

W, wetness; E, enzyme; S, segments.

${ }^{\star} P<0.05,{ }^{\star \star} P<0.01,{ }^{\star \star \star} P<0.001$.

Mean values were significantly different from those of the dry-diet group or no-enzyme group: $\ddagger P<0.05$.

$\dagger$ For details of diet see Table 1 and p. 298. The wet diet was made by addition of $1.3 \mathrm{~kg}$ water to $1 \mathrm{~kg}$ air-dried diet. The feed enzyme was included at $1 \mathrm{~g} / \mathrm{kg}$ and contained $(\mathrm{U} / \mathrm{g})$ : xylanase 2700; $\beta$-glucanase < 70; bacillus protease 700 (Finnfeeds International, Marlborough, Wilts., UK).

foods was found to cause a significant increase in the thickness of all tissue layers (except muscle layer) in the proventriculus, whereas its presence in wet foods significantly $(P<0.05)$ reduced the thickness of tissue wall and glands of proventriculus, but not the thickness of other tissue layers (muscle and lining folds) (Table 4).

Wet feeding did not affect the thickness of gizzard glands or of the tissues lining the gizzard while addition of enzyme to dry or wet foods significantly $(P<0.05)$ reduced the thickness of both gizzard tissue layers, with no interaction between enzyme addition and wetting (Table 4).

The height of villi, depth of crypts, the thickness of muscular layer and the number of crypts per villus of the gut, as a mean of digestive segments from duodenum to colon were found to be significantly elevated in the treated animals $(P<0.05)$ (Table 4$)$. The effect of enzyme addition on the thickness of gut tissue layers was not found to be significant, whereas there was a significant interaction between wetting and enzyme addition (Table 4): enzyme addition to dry foods significantly $(P<0.05)$ increased the heights of villi, the depths of crypt layers, the thickness of tunica muscularis and the crypts: villi ratios, whereas the presence of enzyme in wet foods tended to reduce the thickness of the tissue layers, but not significantly so (Table 4).

\section{Crypt cell proliferation rate}

Wetting significantly $(P<0.001)$ reduced the mean CCPR over the whole digestive tract in the crypts in chickens aged $28 \mathrm{~d}$, from 39.4 in the dry control group to 28.7 cells/crypt per $2 \mathrm{~h}$ (SEM 0.36). Enzyme supplementation was also found to significantly reduce CCPR, from 38.90 in the control group without enzyme to $29 \cdot 2$ cells/crypt per 2 h (SEM $0 \cdot 36$ ). A significant interaction was observed between the effects of wetting and enzyme in which CCPR was significantly $(P<0.05)$ higher in birds given dry food without enzyme supplementation, compared with those given dry food with enzyme or wet food with or without enzyme. Enzyme addition to dry food significantly reduced CCPR whereas the effect of enzyme was not found to be significant on CCPR in birds given wet foods, and CCPR was significantly lower with wet food without enzyme than dry food without enzyme.

\section{Discussion}

In the present experiment, significantly higher food intake and live-weight gain were observed in birds receiving wheat-based food with the addition of $1.3 \mathrm{~kg}$ water $/ \mathrm{kg}$ airdried food, compared with those given the same food in the dry form. Wetting reduced digesta viscosity as did the addition of exogenous enzyme, but the latter did not significantly affect food intake or live-weight gain. Possible reasons for this discrepancy will be explored.

\section{Wet feeding}

The increased live-weight gain in broiler chickens with wet food based on a high proportion of ground wheat was not accompanied by a significant improvement in FCE, suggesting that the birds with wet food grew faster because they ate more than those with dry food. This agreed with the results of Yasar \& Forbes (1999) under similar conditions but was in contrast to the earlier findings (Yalda \& Forbes, 1995, 1996) where broiler chickens given wet commercial pelleted feed had a significantly higher FCE, with little or no increase in food intake. However, during the period in the present experiment in which the wet-fed birds gained $2285 \mathrm{~g}$, those on dry food gained only $1400 \mathrm{~g}$. During the time the wet-fed birds were gaining $1400 \mathrm{~g}$ their FCE would, presumably, have been much higher than those fed dry food and it is commercial practice to 'correct' FCE for differences in body weight. Therefore, it is reasonable to reinterpret the data as suggesting that wet feeding did increase FCE, compared with dry feeding, when equivalent 
periods of growth are compared. Possible causes of this are discussed later.

There are several possible reasons for the increased food intake with wet feeding: increased rate of passage; improved palatability; improved nutrient balance; restricted water intake.

Rate of passage. Wet feeding has been shown to be associated with faster rate of passage of digesta through the tract (Gohl \& Gohl, 1977), linked to a reduction in digesta viscosity (Gohl et al. 1978). The evidence for increased rate of passage is indirect in the present experiment as it was not measured. Comparison of results in Tables 2 and 3 shows that daily food intake was increased more by wet feeding than was the weight of digesta in the whole digestive tract, which would suggest a $13 \%$ faster feed passage with wet food. The shorter time spent by digesta in the gut would tend to reduce digestion and absorption which might have approximately equaled the potential increase in absorption expected from wet feeding. The work of Almirall \& Garcia (1994) showed a positive relationship between the rate of feed passage and feed intake in young broilers but the extent to which this was a causal relationship is not known. Van Der Klis \& Van Voorst (1993) noted a slowing of digesta passage when carboxymethyl cellulose was incorporated into the diet to greatly increase digesta viscosity and it is reasonable to conclude that the reduction in viscosity caused the increased rate of passage. However, it is not clear why the exogenous enzyme did not increase voluntary food intake when it had a similar effect on rate of passage as did wetting.

Palatability. It is unlikely that the greater intake of food DM with wet feeding is due to an improvement in palatability. Palatability is a complex concept in which the preference shown for a food is, in the long-term, related to the learned association between the sensory properties of a food and the adequacy of nutrient supply and balance after eating that food (Forbes, 1995). Simply changing the flavour or texture of food does not result in long-lasting changes in intake or preference whereas changing the nutrient properties of the food frequently does affect intake and preference. Given a choice between wet and dry food from the same source, chicks initially preferred the one to which they had previously become accustomed, but within 1 week were eating almost exactly equal proportions of DM from each (AY Yalda and JM Forbes, unpublished results). Thus, however much it might be thought that wet food is attractive to chickens, there is nothing to suggest that this would cause the long-term large increases in food intake observed in this experiment.

Nutrient supply. The third possibility is that intake was increased by wet feeding due to a more appropriate balance of nutrients being absorbed compared with dry food. Given the very large increase in the weight of digesta in the crop due to wet feeding (Table 3), it is likely that there was appreciable digestion occurring in that organ, due both to activation of endogenous enzymes in the food and to fermentation by microbial action. This digestion could have included partial cleavage of NSP by endogenous phytase in the wheat and/or partial breakdown of cell walls, leading to the observed reduction in digesta viscosity and thus to a greater capacity to ingest food. The potential for improved nutrient absorption was offset by the increased rate of passage with wet feeding, resulting in no overall effect of diet on the proportion of the food retained in the body.

Restriction of water intake. A fourth possibility to account for the large increase in food intake and live-weight gain with wet feeding is that the water intake of the dry-fed birds was restricted by the use of individual nipple drinkers. Water restriction depresses food intake, approximately in proportion to the degree of restriction (Kellerup et al. 1965) although it has been suggested that broiler chickens drink more than they need, perhaps due to boredom (Yeomans, 1986). The total water intakes of the dry-fed birds were significantly lower than those of wet-fed birds, even though the latter took less water from the drinkers as they had a high intake from that incorporated with the wet food. However, both treatments resulted in similar water intake : food intake ratios which might suggest that the dry-fed birds were not short of water, although it is worth noting that in some previous experiments on wet feeding the water intake : food intake ratios were significantly higher for wet-fed birds than for dry-fed birds (Yalda \& Forbes, 1995). Previous work with broilers in the same conditions, including nipple drinkers, as the ones reported here did not result in such a marked depression in performance of the dry-fed birds (Yalda \& Forbes, 1996) but, despite this, it is not possible to rule out water restriction as a reason for the poor performance of the broilers given food in the dry form in the present experiment.

\section{Exogenous enzyme addition}

In contrast to the large effect of wetting, enzyme addition to foods, whether dry or wet, did not result in significant increases in food intake, weight gain or FCE in the present experiment. This was in contrast to earlier results (Yalda \& Forbes, 1996) and the expectation that addition of an enzyme with high arabinoxylanase activity to a wheatbased diet would result in significant improvement in bird performance. Enzyme addition to commercial pelleted foods has often been found to increase live-weight gain with a significant improvement in FCE although these responses to enzyme were highly variable between studies (Rose \& Arscott, 1962; Burnett, 1966; Adams \& Naber, 1969; White et al. 1981; Classen et al. 1985; Fengler et al. 1988; Pawlic et al. 1990; Bedford et al. 1991; Friesen et al. 1992; Graham \& Petterson, 1992; Almirall et al. 1995), probably related to the rate of enzyme inclusion and the type and inclusion rate of ground cereal grains (summarised by Yasar, 1998).

Birds fed on diets with added enzymes have been found not to increase food intake while there is most often a significant increase in FCE which has been speculated to be due to the partial degradation of viscous, gel-forming compounds present in the grain cell-wall materials by enzymes (for review see Bedford, 1995). In a recent study, despite significant reductions in digesta viscosity with wheat-based diets due to enzymes, there appeared to be no significant effect on weight gain or food intake but a significant increase in FCE accompanied by an increase in 
the metabolisibility of dietary energy (Allen et al. 1997). In the present case trends for higher FCE and weight gains obtained with enzyme were not significant even though there was significantly lower digesta viscosity.

Lack of response to the enzyme supplementation in the present case may have been due to an insufficient rate of enzyme inclusion, as Willingham et al. (1959), Rose \& Arscott (1962) and Mannion (1981) found that increasing the inclusion level of enzyme resulted in significant improvement in FCE and weight gain. However, the activity of the enzyme (arabinoxylanase) seems to have been appropriate for this wheat-based diet as it significantly reduced viscosity. In addition, the enzyme added had some protease activity but we did not measure $\mathrm{N}$ retention in this experiment so cannot say whether or not the protease had a beneficial effect.

Ritz et al. (1995a) found that enzyme supplementation did not affect the rate of digesta passage although there was a reduction in digesta viscosity. Bedford (1993) and Choct et al. (1996) also found that reduction in digesta viscosity with enzyme is most probably associated with a partial degradation of NSP, which in turn results in improved FCE, rather than an increase in the rate of passage that may cause food intake to increase. These findings were, however, in contrast to the results of Almirall \& Garcia (1994), in which enzyme reduced the digesta viscosity but also increased the rate of feed passage and the food intake.

The effect of enzyme on gut size was not very consistent; enzyme addition gave an increase in the gut length and weight with dry food, but a decrease with wet food, although the relative gut weights ( $\mathrm{g} / \mathrm{kg}$ body weight) significantly decreased with enzyme addition to both dry and wet food. The latter is frequently found with enzyme supplementation (Brenes et al. 1993; Viveros et al. 1994; Ritz et al. 1995b).

Enzyme supplementation of wheat-based diet, whether dry or wet, reduced total water intake. Bedford (1995) observed that enzyme addition to broiler foods significantly reduced the water in faecal output by approximately $23 \%$ compared with control foods while Van Der Klis \& Van Voorst (1993) found that feeding NSP caused an increase in the water content of the digesta. Enzyme supplementation and water treatment have been reported to alleviate the problems of high water consumption by birds and the production of sticky droppings associated with viscous grains (Gohl et al. 1978; McNab \& Smithard, 1992), presumably by reducing the amounts of NSP in the digesta.

\section{Structure and function of digestive tract}

Savory (1975) and Savory \& Gentle $(1976 a, b)$ stated that increased levels of fibre in the broiler diet lead to compensatory increases in food intake and as a consequence of this the digestive tract increases in length and weight although there is no change in the villi heights. Such differences in the gut size between birds given low- or high-fibre diets are most probably due to the differences in food intake rather than dietary fibre per se. In the present case, the birds given wet food ate significantly larger amounts of food DM and had longer and heavier digestive tracts than those given the same food in dry form. These increases in dimensions of the digestive tract are approximately proportional to the increase in body weight and might, therefore, be a general consequence of faster growth, rather than a mechanism for the achievement of that growth.

As the bird ages it seems to be able to cope better with NSP and such treatments as wetting and exogenous enzymes might be most beneficial in young birds. The viscosity of digesta was low at all ages at which it was measured in those birds which had water and/or enzyme added to the food (mean of all segments $<4 \mathrm{kPa} \cdot \mathrm{s}$, Fig. 3). In contrast, those given dry food without enzyme had very high digesta viscosities (about $11 \mathrm{kPa} \cdot \mathrm{s}$ ) at $14 \mathrm{~d}$, falling to $<4 \mathrm{kPa} \cdot \mathrm{s}$ at $28 \mathrm{~d}$. This supports the observation that wet feeding is more effective in improving DM retention and/or efficiency in younger birds (Yasar \& Forbes, 1999).

The structure of the gut as well as its size appeared to be affected by the intestinal environment. In the proventriculus and the gizzard, wetting significantly increased the thickness of all tissue layers, in parallel with an increase in liveweight gain and gut size. The effect of enzyme was, however, found to be different, depending on the segment of the foregut and the form of food. In the proventriculus, the thickness of tissue layers increased with dry food and there was a decrease with wet food in the presence of enzyme. However, enzyme supplementation reduced the thickness of tissue layers in the gizzard with both dry and wet foods. Viscous NSP have been shown to decrease the density of crypts and villi as well as their thickness, but to increase the rates of enterocyte division in rats (Johnson et al. 1984) and chickens (Viveros et al. 1994), as was found with broiler chickens in the present experiment. Wet feeding increased the height of villi, the thickness of crypt and muscle layers in the intestinal segments and significantly reduced the CCPR. Enzyme supplementation increased the thickness of intestinal tissue layers in dry-fed birds whereas there was a reduction in these variables in wet-fed birds, reflecting the similar trend in the gut size with enzyme. This effect of enzyme was found to be more pronounced for the duodenum, proximal, middle and distal part of the small intestine than the caecum and colon. The increased digestive tract size, villi heights and crypt depths with the use of enzyme in dry food in our experiment is in contrast to the results of Viveros et al. (1994). However, the results obtained in the present study from the wet foods with enzyme were found to be quite similar to the results of Viveros et al. (1994). Similarly, enzyme addition has been found to reduce CCPR in broiler chickens given rye-based diets (Silva \& Smithard, 1996).

In terms of digestive function, these various changes in gut dimensions and cell proliferation support the notion of an increased rate of passage with wet feeding. The increased height of villi and number of crypts per villus and crypt depth point to increased secretion of succus entericus and increased absorptive area. The thicker muscular layer points to increased propulsive function and the reduced CCPR indicates reduced costs of maintaining gut integrity. That CCPR was reduced even though the layers of the gut wall were thicker in wet-fed birds emphasises the magnitude of this effect and the large potential saving in nutrients for maintenance of digestive function due to wet feeding. The significant interaction between effects of wetting and 
enzyme addition on the weights and lengths of the digestive tract, heights of villi, the depths of crypt layer, the thickness of tunica muscularis, the crypts : villi ratio and CCPR, in which there was no additional effect of enzyme addition in wet-fed birds, supports the notion stated earlier, that predigestion in the crop with wet food replaces many of the actions of exogenous enzyme.

In conclusion, wet feeding caused very large and significant increases in food intake and growth rate, but with no change in FCE. Enzyme supplementation had little effect on intake and growth, perhaps because the inclusion level was not sufficient for the high-wheat food. Both wetting and enzyme reduced CCPR and digesta viscosity but neither of these could be the cause of the increase in intake and growth with wet feeding as such increases were not seen with the enzyme.

\section{Acknowledgements}

S. Yasar was on leave and received financial support from the Suleyman Demirel University, Turkey. We are grateful for the supply of enzyme from Dr M. R. Bedford, Finnfeeds International, Marlborough, Wilts., UK.

\section{References}

Adams OL \& Naber EC (1969) Effect of physical and chemical treatments of grains on growth of and feed utilisation by the chick. Poultry Science 48, 853-858.

Allen CM, McCracken KJ \& Bedford MR (1997) Effect of fat type, level of wheat inclusion and enzyme supplementation on diet metabolisability and broiler performance. British Poultry Science 38, S25-S26.

Almirall M, Francesch M, Perez-Vendrell AM, Brufau J \& EsteveGarcia E (1995) The differences in intestinal viscosity produced by barley and $\beta$-glucanase alter digesta enzyme activities and ileal nutrient digestibilities more in broiler chicks than in cocks. Journal of Nutrition 125, 947-955.

Almirall M \& Garcia EE (1994) Rate of passage of barley diets with chromium oxide: Influence of age and poultry strain and effect of $\beta$-glucanase supplementation. Poultry Science 73, $1433-1440$

Annison G (1991) Relationship between the levels of non-starch polysaccharides and the apparent metabolisable energy of wheat assayed in broiler chickens. Journal of Agriculture and Food Chemistry 39, 1252-1256.

Bedford MR (1993) Mode of action of feed enzymes. Journal of Applied Poultry Research 2, 85-92.

Bedford MR (1995) Mechanism of action and potential environmental benefits from the use of feed enzyme. Animal Feed Science and Technology 53, 145-155.

Bedford MR \& Classen HL (1992) Reduction of intestinal viscosity through manipulation of dietary rye and pentosanase concentration of the intestinal aqueous phase and results in improved growth rate and food conversion efficiency of broiler chicks. Journal of Nutrition 122, 560-569.

Bedford MR, Classen HL \& Campbell GL (1991) The effect of pelleting, salt, and pentosanase on the viscosity of intestinal contents and the performance of broilers fed rye. Poultry Science 70, 1571-1577.

Bell DJ \& Freeman BM (1971) Physiology and Biochemistry of the Domestic Fowl, vol. 1. London: Academic Press.

Brenes A, Smith M, Guenter W \& Marquardt RR (1993) Effect of enzyme supplementation on the performance and digestive tract size of broiler chickens fed wheat- and barley-based diets. Poultry Science 72, 1731-1739.

Burnett GS (1966) Studies of viscosity as probable factor involved in the improvement of certain barleys for chickens by enzyme supplementation. British Poultry Science 7, 55-75.

Choct M \& Annison G (1990) Anti-nutritive effect of wheat pentosans in broiler diets. British Poultry Science 31, 811-821.

Choct M \& Annison G (1992) Anti-nutritive effect of wheat pentosans in broiler chickens: roles of viscosity and gut microflora. British Poultry Science 33, 821-834.

Choct M, Hughes RJ, Wang J, Bedford MR, Morgan AJ \& Annison G (1996) Increased small intestinal fermentation is partly responsible for the anti-nutritive activity of non-starch polysaccharides in chickens. British Poultry Science 37, 609-621.

Classen HL, Campbell GL, Rossnagel BG, Bhatty R \& Reichert RD (1985) Studies on the use of hulless barley in chick diets: Deleterious effects and methods of alleviation. Canadian Journal of Animal Science 65, 725-733.

Edwards CA, Wilson RG, Hanlon L \& Eastwood MA (1992) Effect of the dietary fibre content of lifelong diet on colonic cellular proliferation in the rat. Gut 33, 1076-1079.

Fengler A \& Marquardt RR (1988) Water soluble pentosans from rye: 2 . Effects on rate of dialysis and on the retention of nutrients by the chick. Cereal Chemistry 64, 1076-1079.

Fengler A, Pawlic JR \& Marquardt RR (1988) Improvement in nutrient retention and changes in excreta viscosities in chicks fed rye-containing diets supplemented with fungal enzymes, sodium taurocholate and penicillin. Canadian Journal of Animal Science 68, 483-491.

Forbes JM (1995) Voluntary Food Intake and Diet Selection in Farm Animals. Wallingford: CAB International.

Friesen OG, Guenter W, Marquardt RR \& Rotter BA (1992) The effect of enzyme supplementation on the apparent metabolisable energy and nutrient digestibilities of wheat, barley, oats and rye for young broiler chicks. Poultry Science 71, 1710-1721.

Gohl B, Alden S, Eldwinger K \& Thomke S (1978) Influence of $\beta$-glucanase on feeding value of barley for poultry and moisture content of excreta. British Poultry Science 19, 41-47.

Gohl B \& Gohl I (1977) The effect of viscous substances and the transit time of barley digesta in rats. Journal of the Science of Food and Agriculture 28, 911-915.

Goodlad RA \& Wright NA (1982) Quantitative studies on epithelial replacement in the gut. Digestive Physiology P212, $1-23$.

Graham H \& Petterson D (1992) A note on the effect of betaglucanase and a multi-enzyme on production in broiler chicks fed a barley-based diet. Swedish Journal of Agricultural Research 22, 39-42.

Johnson IT, Gee JM \& Mahoney RR (1984) Effect of dietary supplements of guar gum and cellulose on intestinal cell proliferation, enzyme levels and sugar transport in the rat. British Journal of Nutrition 52, 447-487.

Kellerup SU, Parker JE \& Arscott GH (1965) Effect of restricted water consumption on broiler chickens. Poultry Science 44, 78-83.

McNab JM \& Smithard RR (1992) Barley $\beta$-glucan: an antinutritional factor in poultry feeding. Nutrition Research Reviews 5, 45-60.

Mannion PF (1981) Enzyme supplementation of barley based diets for broiler chickens. Australian Journal of Experimental Agriculture and Animal Husbandry 21, 296-302.

Moran ET, Lall SP \& Summers JD (1969) The feeding value of rye for the growing chick: Effect of enzyme supplements, antibiotics, autoclaving and geographical area of production. Poultry Science 48, 939-949. 
Pawlic JR, Fengler A \& Marquardt RR (1990) Improvement of the nutritional value of rye by the partial hydrolysis of the viscous water-soluble pentosans following water-soaking or fungal enzyme treatment. British Poultry Science 31, 525-538.

Petterson D \& Aman P (1989) Enzyme supplementation of a poultry diet containing rye and wheat. British Journal of Nutrition 62, 139-149.

Ritz CW, Hulet RM, Self BB \& Denbow DM (1995a) Effects of protein level and enzyme supplementation upon growth and rate of digesta passage of male turkeys. Poultry Science $\mathbf{7 4}$, $1323-1328$.

Ritz CW, Hulet RM, Self BB \& Denbow DM (1995b) Growth and intestinal morphology of male turkeys as influenced by dietary supplementation of amylase and xylanase. Poultry Science $\mathbf{7 4}$, $1329-1334$

Rose RJ \& Arscott GH (1962) Use of barley in high-efficient broiler rations: 5. Further studies on the use of enzymes, soaking and pelleting barley for chicks. Poultry Science 41, 124-130.

Savory CJ (1975) Effects of group size on the feeding behaviour and growth of chicks. British Poultry Science 16, 343-350.

Savory CJ \& Gentle MJ (1976a) Effects of dietary dilution with fibre on the food intake and gut dimensions of Japanese quail. British Poultry Science 17, 561-570.

Savory CJ \& Gentle MJ (1976b) Changes in food intake and gut size in Japanese quail in response to manipulation of dietary fibre content. British Poultry Science 17, 571-580.

Silva SSP \& Smithard RR (1996) Exogenous enzymes: crypt cell proliferation, digesta viscosity short chain fatty acids and xylanases in the jejunum. British Poultry Science 37, S77.

Turk DA (1982) The anatomy of the avian digestive tract related to feed utilisation. Poultry Science 61, 1225-1244.

Van Der Klis JD \& Van Voorst A (1993) The effect of carboxy methyl cellulose (a soluble polysaccharide) on the rate of marker excretion from the gastrointestinal tract of broilers. Poultry Science 72, 503-512.
Van Der Klis JD, Van Voorst A \& Van der Cruyningen C (1993a) Effect of a soluble polysaccharide (carboxy methyl cellulose) on the absorption of minerals from the gastrointestinal tract of broilers. British Poultry Science 34, 985-997.

Van Der Klis JD, Van Voorst A \& Van der Cruyningen C (1993b) Effect of a soluble polysaccharide (carboxy methyl cellulose) on the physico-chemical conditions in the gastrointestinal tract of broilers. British Poultry Science 34, 971-983.

Viveros A, Brenes A, Pizzaro M \& Castano M (1994) Effect of enzyme supplementation of a diet based on barley, an autoclave treatment, on apparent digestibility, growth performance and gut morphology of broilers. Animal Feed Science and Technology 48, 237-251.

White WB, Bird HR, Sunde ML, Prentice N, Burger WC \& Marlett JA (1981) The viscosity interaction of barley beta-glucan with Trichoderma viride cellulase in chick intestine. Poultry Science 60, 1043-1048.

Willingham HE, Leong KC, Jensen LS \& McGinnis J (1959) Studies on the role of enzyme supplements and water treatment for improving the nutritional value of barley. Poultry Science 38, 539-544.

Yalda AY \& Forbes JM (1995) Food intake and growth in chickens given food in the wet form with and without access to drinking water. British Poultry Science 36, 357-369.

Yalda AY \& Forbes JM (1996) Effects of food intake, soaking time, enzyme and cornflour addition on the digestibility of the diet and performance of broilers given wet food. British Poultry Science 37, 797-807.

Yasar S (1998) Assessment of the Nutritional Effects of Water Treatment of Food for Poultry. PhD Thesis, University of Leeds.

Yasar S \& Forbes JM (1999) Performance and gastro-intestinal response of broiler chickens fed on cereal grain-based foods soaked in water. British Poultry Science 40, 65-76.

Yeomans MR (1986) Overdrinking in the domestic fowl. British Poultry Science 27, 163. 